\title{
An investigation into the electro-oxidation of ethanol and 2-propanol for application in direct alcohol fuel cells (DAFCs)
}

\author{
SAGAR SEN GUPTA and JAYATI DATTA* \\ Department of Chemistry, Bengal Engineering and Science University, Shibpur, Howrah 711 103, India \\ e-mail: jayatids@ hotmail.com
}

MS received 24 March 2004; revised 1 March 2005

\begin{abstract}
A comparative study of the electro-oxidation of ethanol and 2-propanol was carried out on carbon-supported platinum particles. Cyclic voltammetry, steady state polarisation, and electrochemical impedance spectroscopy were used to investigate the oxidation reactions. A difference in the mechanistic behaviour of the oxidation of ethanol and 2-propanol on Pt was observed, thereby highlighting the fact that the molecular structure of the alcohol has great influence on its electroreactivity. The study emphasizes the fact that 2-propanol is a promising fuel candidate for a direct alcohol fuel cell.
\end{abstract}

Keywords. Platinized carbon electrode; ethanol; 2-propanol; electro-oxidation, charge transfer resistance.

\section{Introduction}

Fuel cells employing organic fuels are attractive as power sources for electric vehicles and for both stationary and portable applications. ${ }^{1}$ In liquid-fed fuel cells, an aqueous solution of an organic fuel, such as methanol, is oxidized at the anode while oxygen is reduced to water at the cathode. The oxidation of methanol in a direct methanol fuel cell (DMFC) has been investigated for more than three decades. ${ }^{2-6}$ Only recently has the concept of polymer electrolyte membrane fuel cell (PEMFC) been applied to the DMFC leading to greater improvement in terms of efficiency and power density. Nevertheless, its performance is still limited because of several problems: (i) the relatively slow kinetics of methanol oxidation at the anode, which leads to high overpotentials, (ii) anode poisoning by strongly adsorbed intermediates formed during methanol oxidation, and (iii) the high extent of methanol crossover through the Nafion membrane, which depolarises the oxygen cathode.

Moreover, methanol has some particular disadvantages, e.g. it is relatively toxic, inflammable with low boiling point and is not a primary fuel. Therefore, other alcohols are being considered as alternative fuels. ${ }^{7-10}$ Ethanol is an attractive fuel since it can be easily produced in large amount by the fer-

*For correspondence mentation of sugar-containing raw materials from agriculture. The use of alcohols with longer chains for applications in fuel cells can also be attractive considering the higher energy content of the fuel. As given in table 1, such alcohols have a very good energy density $\mathrm{W}_{\mathrm{e}}$, close to that of hydrocarbons and gasoline (e.g. $10-11 \mathrm{kWh} / \mathrm{kg}$ ), so that they appear as alternative fuels for electric vehicles.

Iwasita $e a^{11}$ have used SNIFTIRS to investigate ethanol electrooxidation at a polycrystalline platinum electrode in $\mathrm{HClO}_{4}$ solution. The comparison of spectra using $s$ - and $p$-polarized light allowed distinguishing between bulk products and adsorbed species. Only linearly adsorbed $\mathrm{CO}$ was detected as a surface species. They reported that at high ethanol concentration less $\mathrm{CO}_{2}$ and $\mathrm{CH}_{3} \mathrm{COOH}$ were formed and $\mathrm{CH}_{3} \mathrm{CHO}$ became the main product. Leung et al $l^{12}$ demonstrated the sensitiveness of ethanol electrooxidation to the metal crystallographic orientation. While only small CO coverages $(\theta \approx 0 \cdot 1)$ were obtained on ordered $\mathrm{Pt}$ (111) for ethanol concentrations of $0 \cdot 05-0.5 \mathrm{M}$, sub-

Table 1. Thermodynamic data associated with the electrochemical oxidation of some alcohols (under standard conditions.

\begin{tabular}{lccc}
\hline Fuel & $\Delta G^{0}(\mathrm{~kJ} / \mathrm{mol})$ & $E_{\text {cell }}(\mathrm{V})$ & $W_{e}(\mathrm{kWh} / \mathrm{kg})$ \\
\hline $\mathrm{CH}_{3} \mathrm{OH}$ & -702 & $1 \cdot 213$ & $6 \cdot 09$ \\
$\mathrm{C}_{2} \mathrm{H}_{2} \mathrm{OH}$ & -1325 & 1.145 & 8.00 \\
$\mathrm{C}_{3} \mathrm{H}_{3} \mathrm{OH}$ & -1853 & 1.067 & 8.58 \\
\hline
\end{tabular}


stantially higher $\mathrm{CO}$ coverages were obtained for disordered Pt (111) and especially polycrystalline Pt. Tremiliosi-Filho et $a l^{13}$ observed rather weak reactivity of ethanol at a gold electrode in acid medium. In this work acetaldehyde was reported to be the primary product of the electrooxidation of ethanol.

The absence of linear adsorbed $\mathrm{CO}$ from 2-propanol in contrast to 1-propanol and other $1^{\circ}$ alcohols has been widely reported. ${ }^{14-16}$ This fact appears as a difference in the electrochemical behaviour of $1^{\circ}$ and $2^{\circ}$ alcohols on Pt and suggests a high energy barrier for the cleavage of the $\mathrm{C}-\mathrm{C}$ bond for the latter compounds. S-G. Sun et $a l^{14,15}$ studied the electrocatalytic oxidation of isopropanol on a number of $\mathrm{Pt}$ single crystal electrodes. It was determined that acetone and $\mathrm{CO}_{2}$ are the main product species involved in isopropanol oxidation. It was shown that at all $\mathrm{Pt}$ single crystal electrodes studied, the production of acetone was faster than that of $\mathrm{CO}_{2}$ in isopropanol oxidation. Applying ac-impedance spectroscopy to the analysis of the electrooxidation of 2-propanol and methanol on carbon-supported Pt electrodes, Omoto et $a l^{16}$ reported that the reaction rate of the intermediate for 2-propanol was lower than that of methanol. In a low potential region, however, the overall oxidation rate of 2-propanol was higher than methanol, suggesting a direct reaction path from 2-propanol to acetone, which does not go through an intermediate, could be involved.

To date, the best performing fuel cell electrodes are either platinum or platinum-based materials, including the anode in a direct alcohol fuel cell (DAFC). ${ }^{17-19}$ Platinum has been one of the most expensive materials in the fabrication of components for these fuel cells. Fur sufficient activity towards alcohol electrooxidation at least a few $\mathrm{mg} / \mathrm{cm}^{2}$ of platinum is still required. It is therefore necessary to develop more active catalysts for DAFC to be economically viable. Various routes adopted to achieve this goal include synthesis of finely dispersed catalyst layer, ${ }^{20-22}$ reduction of relative loading of $\mathrm{Pt}$ on the catalyst surface by introducing a second promoting metal ${ }^{23-26}$ and employing substrate that not only offers enhanced surface area but also assist in the catalytic activity of the noble metal deposits during electro-oxidation of the fuel. ${ }^{27,28}$

In this paper, we present some investigations on the electrooxidation of ethanol and 2-propanol on carbon supported platinum particles. By doing this, we are able to get insights into the kinetics and mechanism of electrooxidation of these organic fuels.

\section{Experimental}

Graphite plate saw-cut finish grade (GLF-HD, Graphite India Ltd.), of thickness approximately $2 \mathrm{~mm}$, was used as support for platinum deposits. Galvanostatic deposition of platinum was made from a solution containing $0.05 \mathrm{M} \mathrm{H}_{2} \mathrm{PtCl}_{6}$ (AR grade, from Arora Matthey Ltd.), in $2 \mathrm{M} \mathrm{HCl}$ at a current density of $3 \mathrm{~mA}$ $\mathrm{cm}^{-2}$. Different loading of platinum was achieved by varying the deposition time. The platinum loading was determined by the mass difference of the carbon supports before and after platinization. The carbon supports were boiled in triply distilled water for $20 \mathrm{~min}$ prior to deposition and dried for $1 \mathrm{~h}$ at $363 \mathrm{~K}$ to constant mass both before and after deposition.

Electrochemical experiments were performed using a computer-controlled Autolab (Eco Chieme) with potentiosat/galvanostat PG STAT 12 and FRA modules. A conventional H-type glass cell with a platinum foil counter electrode and a mercury/mercurous sulphate (MMS) reference electrode ( $0.68 \mathrm{~V}$ vs RHE) was used for all electrochemical experiments. Unless otherwise stated, potentials in this paper are expressed relative to MMS. The apparent area of the $\mathrm{Pt} / \mathrm{C}$ electrode exposed to the solution was always $0.65 \mathrm{~cm}^{2} . \mathrm{N}_{2}$ gas (XL grade from BOC India Ltd.) was bubbled in $0.5 \mathrm{M} \mathrm{H}_{2} \mathrm{SO}_{4}$ supporting electrolyte for $15 \mathrm{~min}$ before starting each electrochemical experiment. All solutions were prepared with triply distilled water.

For the determination of the electrochemically active surface area of $\mathrm{Pt} / \mathrm{C}$ electrodes, cyclic voltammograms were recorded after $30 \mathrm{~min}$ of potential cycling in $0.5 \mathrm{M} \mathrm{H}_{2} \mathrm{SO}_{4}$ between the limits -0.7 to $0.9 \mathrm{~V}$ at a potential sweep rate of $50 \mathrm{mVs}^{-1}$. Ethanol or 2-propanol (AR grade from Merck) was added to the nitrogen saturated $0.5 \mathrm{M} \mathrm{H}_{2} \mathrm{SO}_{4}$ electrolyte to obtain the required concentration. Cyclic voltammograms of the electrooxidation of the alcohols were recorded between -0.6 to $1.0 \mathrm{~V}$ at a sweep rate of $50 \mathrm{mVs}^{-1}$. Steady state potentiostatic data was collected after polarisation for $5 \mathrm{~min}$ in the same solution. Any adsorbed impurities or organic residues were removed by oxidative desorption during the first step at $0.7 \mathrm{~V}$ for $10 \mathrm{~s}$. Any layer of chemisorbed oxygen was reduced during a short step at $-0.5 \mathrm{~V}$ for $2 \mathrm{~s}$ after which the final potential was applied and the current-time curve was recorded. Anodic stripping voltammetry was performed for the determination of acetaldehyde and acetone using VA Computrace System (Metrohm Ltd., Switzerland). ${ }^{29}$ 
For electrochemical impedance measurements, prior to the addition of the organic fuel to the electrolyte, the surface of the working electrode was cleaned electrochemically by cycling the potential between -0.7 and $0.9 \mathrm{~V}$ at $50 \mathrm{mV} / \mathrm{s}$ in $0.5 \mathrm{M} \mathrm{H}_{2} \mathrm{SO}_{4}$ until the cyclic voltammogram stopped changing. After the injection of ethanol, the potential of the electrode was stepped to the desired value. Allowing $30 \mathrm{~s}$ for equilibration, impedance at each measurement potential was obtained between $100 \mathrm{kHz}$ and $10 \mathrm{mHz}$ containing 80 data points. The amplitude (rms value) of the ac signal employed for the EIS studies was $5 \mathrm{mV}$. The entire experiment was repeated for measurement potentials between 400 and $700 \mathrm{mV}$ (vs SHE) spaced at $100 \mathrm{mV}$ intervals.

OCP measurements at different temperatures were carried out in a two-compartment cell with a sintered Gooch separator. The anode compartment was fed with $1 \mathrm{M}$ ethanol or $1 \mathrm{M}$ 2-propanol/0.5 $\mathrm{M} \mathrm{H}_{2} \mathrm{SO}_{4}$ solution while the cathode chamber was continuously purged with oxygen (XL grade from BOC India Ltd.) at a flow rate of $140 \mathrm{ml} / \mathrm{min}$. A Pt electrode $\left(1 \mathrm{~cm}^{2}\right)$ was used as the cathode.

The surface morphology of the electrocatalysts was investigated with a LEO S 430i scanning electron microscope at an accelerating potential of $20 \mathrm{kV}$.

\section{Results and discussion}

\subsection{Electrode characterisation}

Figure 1 shows the cyclic voltammogram for electrodeposited Pt electrode in 0.5 $\mathrm{M} \mathrm{H}_{2} \mathrm{SO}_{4}$. The wellestablished features of hydrogen adsorption, hydrogen

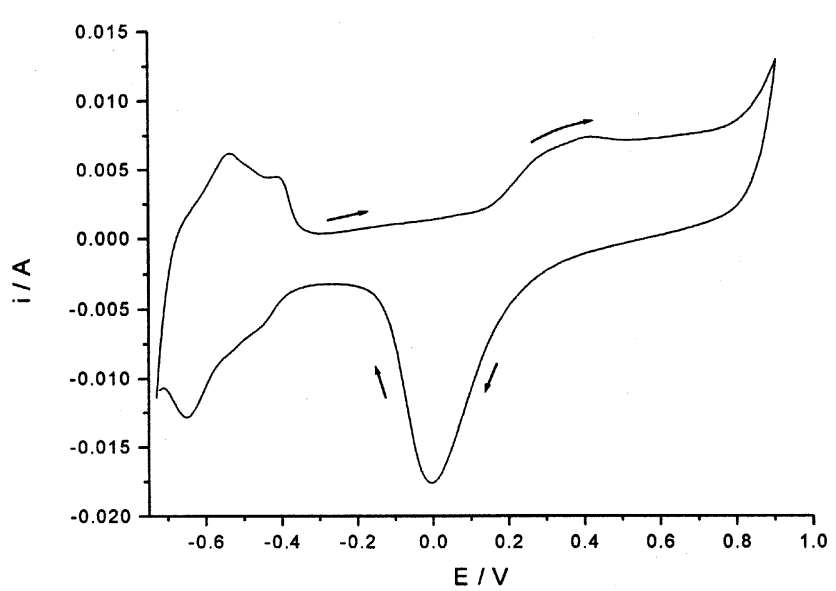

Figure 1. Cyclic voltammogram of platinised carbon electrode in $0.5 \mathrm{M} \mathrm{H}_{2} \mathrm{SO}_{4}$ at a potential sweep rate of $50 \mathrm{mV} \mathrm{s}^{-1}$. desorption, double layer charging, oxide formation and oxide reduction are evident from the peaks in the voltammogram. ${ }^{30}$ The real surface area of a catalyst can be orders of magnitude greater than the geometric area. Since the extent of adsorption and catalytic reaction rates depend on real surface area, it is important to measure this value. A measure of the real electrochemical surface area can be obtained from the charge corresponding to the area under the hydrogen adsorption peaks. It is assumed that each surface platinum atom is associated with one chemisorbed hydrogen atom. Thus

$$
A_{r}=Q_{h} / Q_{m},
$$

where $A_{r}$ is the real electrochemical surface area $\left(\mathrm{cm}^{2} \mathrm{Pt}\right), Q_{h}$ is charge corresponding to the saturated hydrogen coverage on the electrode $(\mu \mathrm{C})$ and $Q_{m}$ is the charge associated with monolayer adsorption of hydrogen $\left(\mu \mathrm{C} \mathrm{cm}^{-2} \mathrm{Pt}\right)$. A theoretical charge of $Q_{m}=$ $210 \mu \mathrm{C} \mathrm{cm}^{-2} \mathrm{Pt}$ was used for the conversion of the hydrogen adsorption charge to the real surface area. ${ }^{31}$ Roughness factor, $R_{f}\left(\mathrm{~cm}^{2} \mathrm{Pt} \mathrm{cm}{ }^{-2}\right)$ describes the enhancement of the real electrochemical surface area in comparison with the geometric area, $A_{g}\left(\mathrm{~cm}^{2}\right)$,

$$
R_{f}=A_{r} / A_{g}
$$

A representative SEM image of the carbon-supported platinum electrode is presented in figure 2 where one can see the distinct array of Pt particles on the carbon substrate. These particles are spherical in shape and relatively uniform in size with diameters ranging between 200 and $250 \mathrm{~nm}$. The clusters cover

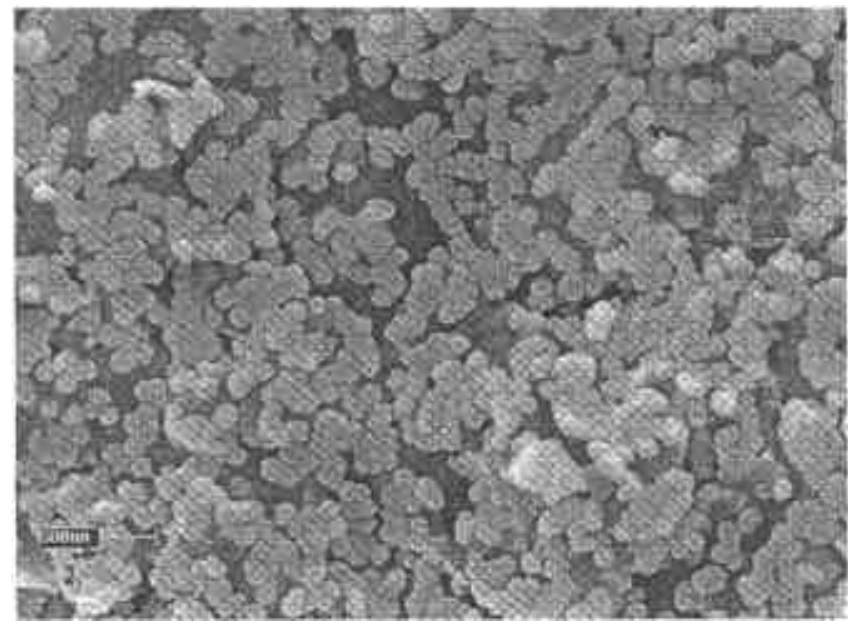

Figure 2. SEM image of electrodeposited platinum on graphite at a current density of $3 \mathrm{~mA} \mathrm{~cm}^{-2}$. Pt loading: $2.9 \mathrm{mg} \mathrm{cm}^{-2}$. 

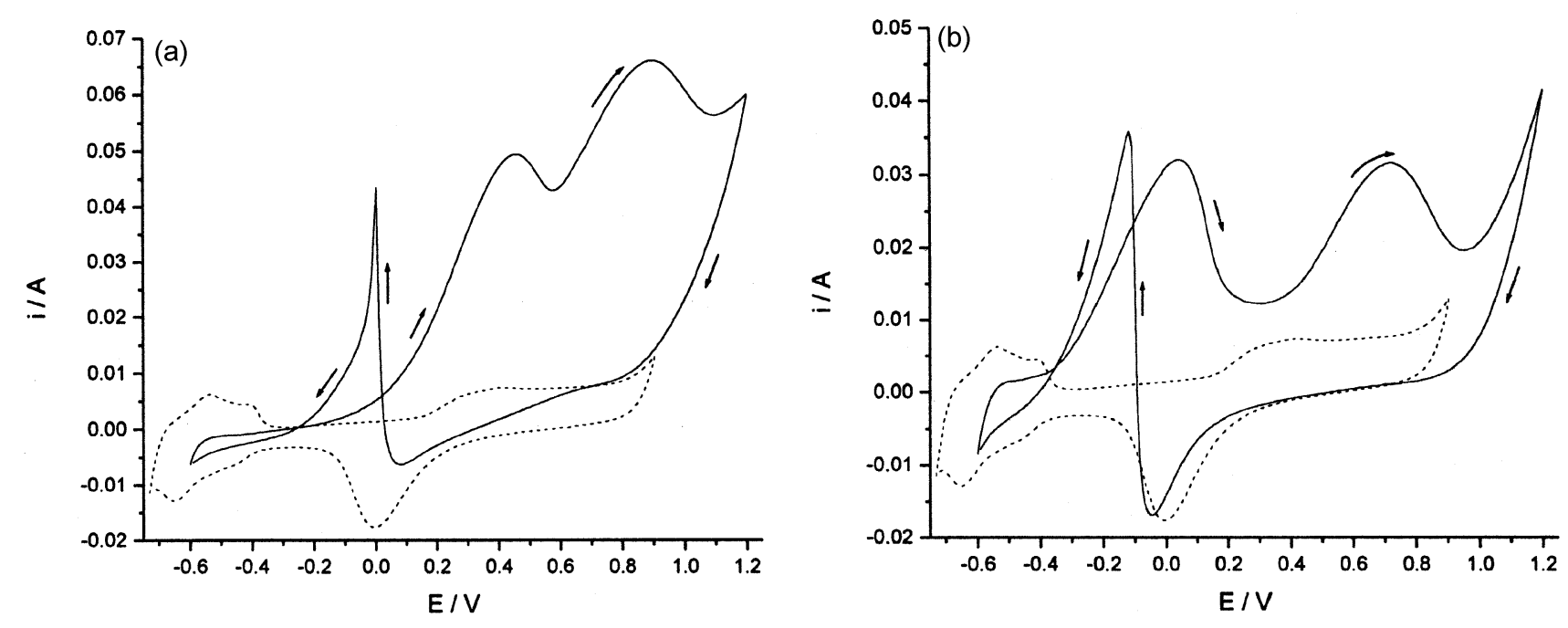

Figure 3. (a) Cyclic voltammogram for carbon supported platinum electrode, scan rate $=50 \mathrm{mV} \mathrm{s}^{-1}:(----) 1 \cdot 0 \mathrm{M}$ ethanol in $0.5 \mathrm{M} \mathrm{H}_{2} \mathrm{SO}_{4}$ and (----) $0.5 \mathrm{M} \mathrm{H}_{2} \mathrm{SO}_{4}$. (b) Cyclic voltammogram for carbon supported platinum electrode, scan rate $=50 \mathrm{mV} \mathrm{s}^{-1}$ : (-_- $1.0 \mathrm{M}$ 2-propanol in $0.5 \mathrm{H}_{2} \mathrm{SO}_{4}$ and (----) $0.5 \mathrm{M} \mathrm{H}_{2} \mathrm{SO}_{4}$.

Table 2. Roughness factor of carbon-supported platinum electrode as determined from the charge corresponding to the hydrogen adsorption peaks in figure 1 .

\begin{tabular}{lcccc}
\hline $\begin{array}{l}\text { Current density } \\
\text { of deposition }\end{array}$ & $\begin{array}{c}\text { Pt loading } \\
\left(\mathrm{mg} \mathrm{cm}^{-2}\right)\end{array}$ & $\begin{array}{c}Q_{h} \\
(\mu \mathrm{C})\end{array}$ & $\begin{array}{c}A_{r} \\
\left(\mathrm{~cm}^{2} \mathrm{Pt}\right)\end{array}$ & $\begin{array}{c}R_{f} \\
\left(\mathrm{~cm}^{2} \mathrm{Pt} \mathrm{cm}^{-2}\right)\end{array}$ \\
\hline $3 \mathrm{~mA} \mathrm{~cm}{ }^{-2}$ & 2.9 & $6.3 \times 10^{4}$ & $302 \cdot 8$ & 468.8 \\
\hline
\end{tabular}

about $85 \%$ of the carbon surface, as determined from the SEM images.

\subsection{Electro-oxidation studies}

3.2a Cyclic voltammetry: Cyclic voltammogram for the electrodeposited $\mathrm{Pt}$ in $1.0 \mathrm{M}$ ethanol $+0.5 \mathrm{M}$ $\mathrm{H}_{2} \mathrm{SO}_{4}$ (solid line in figure $3 \mathrm{a}$ ) during the positivegoing scan displays a higher anodic current in the range $-0 \cdot 25$ to $0 \cdot 2 \mathrm{~V}$ compared with the base electrolyte (dashed line). This excess current is primarily due to the dehydrogenation of ethanol during adsorption. $^{32}$

$$
\mathrm{CH}_{3}-\mathrm{CH}_{2} \mathrm{OH} \rightarrow\left(\mathrm{CH}_{3}-\mathrm{CHO}\right)_{\mathrm{ads}}+2 \mathrm{H}^{+}+2 e^{-} \text {. }
$$

In the potential range between 0 and $0 \cdot 2 \mathrm{~V}$, the dissociative adsorption of water occurs:

$$
\mathrm{Pt}+\mathrm{H}_{2} \mathrm{O} \rightarrow \mathrm{Pt}-\mathrm{OH}_{\mathrm{ads}}+\mathrm{H}^{+}+e^{-} .
$$

At higher electrode potentials $(E>0.2 \mathrm{~V})$ where the water molecule is already activated to form oxygenated species, the oxidation of adsorbed $\mathrm{CH}_{3}-\mathrm{CHO}$ produce acetic acid as follows:

$$
\begin{aligned}
& \left(\mathrm{CH}_{3}-\mathrm{CHO}\right)_{\mathrm{ads}}+\mathrm{Pt}-\mathrm{OH}_{\mathrm{ads}} \rightarrow \\
& \mathrm{CH}_{3}-\mathrm{COOH}+\mathrm{H}^{+}+e^{-}+\mathrm{Pt} .
\end{aligned}
$$

Further oxidation to $\mathrm{CO}_{2}$ is usually difficult on Pt electrodes at room temperature. In the negative-going potential sweep only one anodic peak appears and this is attributed to renewed oxidation of the fuel.

As for the case of ethanol, two regions can be considered during the positive potential cycle of electrodeposited $\mathrm{Pt}$ in a 1.0 M 2-propanol solution in the base electrolyte (figure $3 b$ ); the first one corresponding to the dehydrogenation of the alcohol $(-0.5$ to $-0.25 \mathrm{~V}$ potential range) and the second one associated with bulk oxidation of 2-propanol $(E>-$ $0.25 \mathrm{~V} .{ }^{8}$ The negative-going scan is characterized by an anodic peak at $-0 \cdot 2 \mathrm{~V}$. 
For the electrooxidation of both ethanol and 2propanol, the appearance of two peaks on the anodic sweep can be ascribed to the oxidation of the fuel by two kinds of chemisorbed oxygen species. ${ }^{33}$ A surface layer of Pt-OH is first formed on Pt and this is subsequently transformed into a Pt-O layer.

$$
\begin{aligned}
& \mathrm{Pt}+\mathrm{H}_{2} \mathrm{O} \rightarrow \mathrm{Pt}^{-} \mathrm{OH}_{\mathrm{ads}}+\mathrm{H}^{+}+e^{-}, \\
& 2 \mathrm{Pt}-\mathrm{OH}_{\mathrm{ads}} \rightarrow \mathrm{Pt}-\mathrm{O}+\mathrm{H}_{2} \mathrm{O}+\mathrm{Pt} .
\end{aligned}
$$

On the cathodic return sweep the electrode surface is initially completely covered with oxygen. Renewed oxidation of the fuel can only begin after a part of the oxygen layer has first been reduced. ${ }^{33,34}$ The oxidation peak in the cathodic sweep is thus displaced in the direction of the hydrogen potential.

3.2b Steady state polarization: Tafel plots for the oxidation of ethanol and 2-propanol obtained from the polarisation studies are shown in figure 4 . The polarisation data have been converted with respect to the standard hydrogen electrode (SHE) for convenience. The current densities were calculated using the geometric area of the electrodes. The $E$ vs $\log i$ plots for the oxidation of ethanol and 2-propanol coincide in the potential range from 0.45 to $6.0 \mathrm{~V}$. Otherwise, over the whole potential range studied, the oxidation current for ethanol is smaller than those measured for 2-propanol. It is important to note that for ethanol oxidation, the Tafel slope of $200 \mathrm{mV} \mathrm{dec}^{-1}$ extends over a wide potential range. In contrast, the

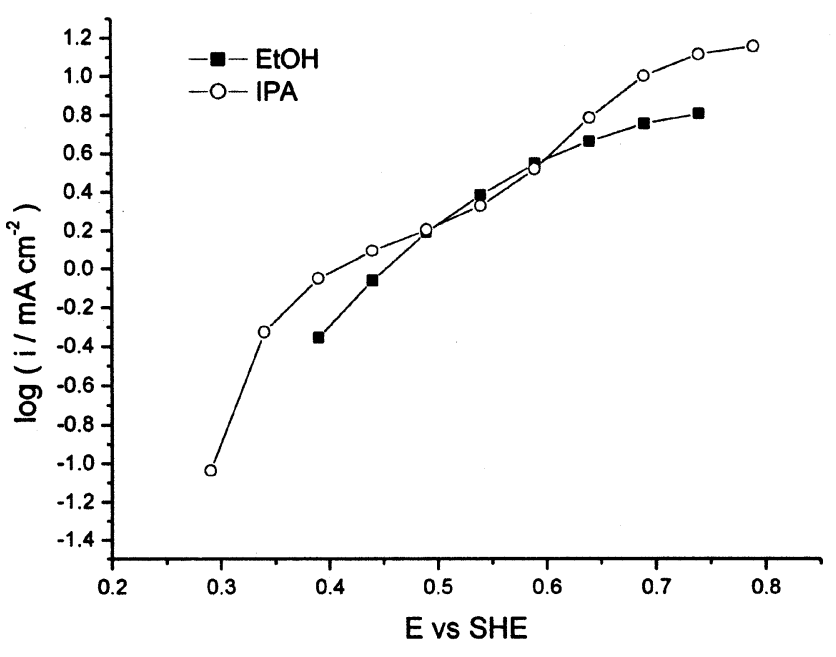

Figure 4. Steady-state polarisation curves of carbon supported platinum electrode: (- --$) 1.0 \mathrm{M}$ ethanol in $0.5 \mathrm{H}_{2} \mathrm{SO}_{4}$ and (--O-) $1.0 \mathrm{M}$ 2-propanol in $0.5 \mathrm{H}_{2} \mathrm{SO}_{4}$. linearity with 2-propanol oxidation breaks at around $0.5 \mathrm{~V}$ to give two slopes: a $95 \mathrm{mV} \mathrm{dec}{ }^{-1}$ between 0.3

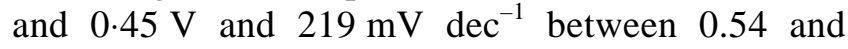
$0.7 \mathrm{~V}$. This fact indicates a major mechanistic difference in the electro-oxidation process between these two alcohols.

It is expected that $\mathrm{C}_{2}$ and $\mathrm{C}_{3}$ alcohols undergo electro-oxidation leading to different soluble products. Investigations made after prolonged and continuous electro-oxidation of ethanol or 2-propanol in $0.5 \mathrm{M} \mathrm{H}_{2} \mathrm{SO}_{4}$ on carbon supported $\mathrm{Pt}$ anode showed the presence of acetaldehyde in solution employing ethanol as fuel whereas acetone was detected as a 2propanol oxidation product. For complete oxidation of $\mathrm{CO}_{2}$, the electrocatalysis of the $\mathrm{C}-\mathrm{C}$ bond cleavage is a topic of interest. Studies undertaken on the electrooxidation of ethanol in acid as well as alkaline medium have shown that the presence of $\mathrm{Ru}$ in the catalyst layers facilitate the cleavage of the $\mathrm{C}-\mathrm{C}$ bond in the ethanol molecule upon adsorption. ${ }^{10,27,35}$ In view of this, detailed studies will be performed in the future using in situ spectrochemical techniques with the aim of attaining a better understanding of the mechanism involved in the oxidation of these organic fuels.

3.2c Electrochemical impedance spectroscopy $(E I S)$ : Figure 5 shows the effect of potential on the Nyquist plot for ethanol and 2-propanol oxidation in $0.5 \mathrm{M} \mathrm{H}_{2} \mathrm{SO}_{4}$. The charge transfer resistance, $R_{c t}$, as measured by the diameter of the semi-circle in the plot, is related to the charge transfer reaction kinetics according to the following equations: ${ }^{36}$

$$
R_{c t}=R T / n F i_{0},
$$

where

$$
i_{0}=n F A k_{0} C_{0}^{*(1-\alpha)} C_{R}^{* \alpha},
$$

$R$ is the molar gas constant, $\mathrm{J} \mathrm{mol}^{-1} \mathrm{~K}^{-1}, T$ the temperature, $K, n$ the number of electrons transferred, $\mathrm{F}$ the Faraday constant, $\mathrm{C}, i_{0}$ the exchange current, A the reaction area, $\mathrm{cm}^{2}, k_{0}$ the standard heterogeneous rate constant, $\mathrm{cm} \mathrm{s}^{-1}, C_{0}^{*}, C_{R}^{*}$ are bulk concentrations of oxidation and reduction species, $\mathrm{mol} \mathrm{l}^{-1}$ and $\alpha$ is the transfer coefficient. The impedance spectra of the electrooxidation of ethanol and 2-propanol in $0.5 \mathrm{M}$ $\mathrm{H}_{2} \mathrm{SO}_{4}$ may be fit to an equivalent circuit (figure 6). This circuit consists of a resistor corresponding to the charge transfer resistance, $R_{c t}$ across the electrode/ electrolyte interface in parallel combination with a constant phase element (CPE) to model the double layer. These electrical components are then combined with the solution resistance, $R_{s}$. 

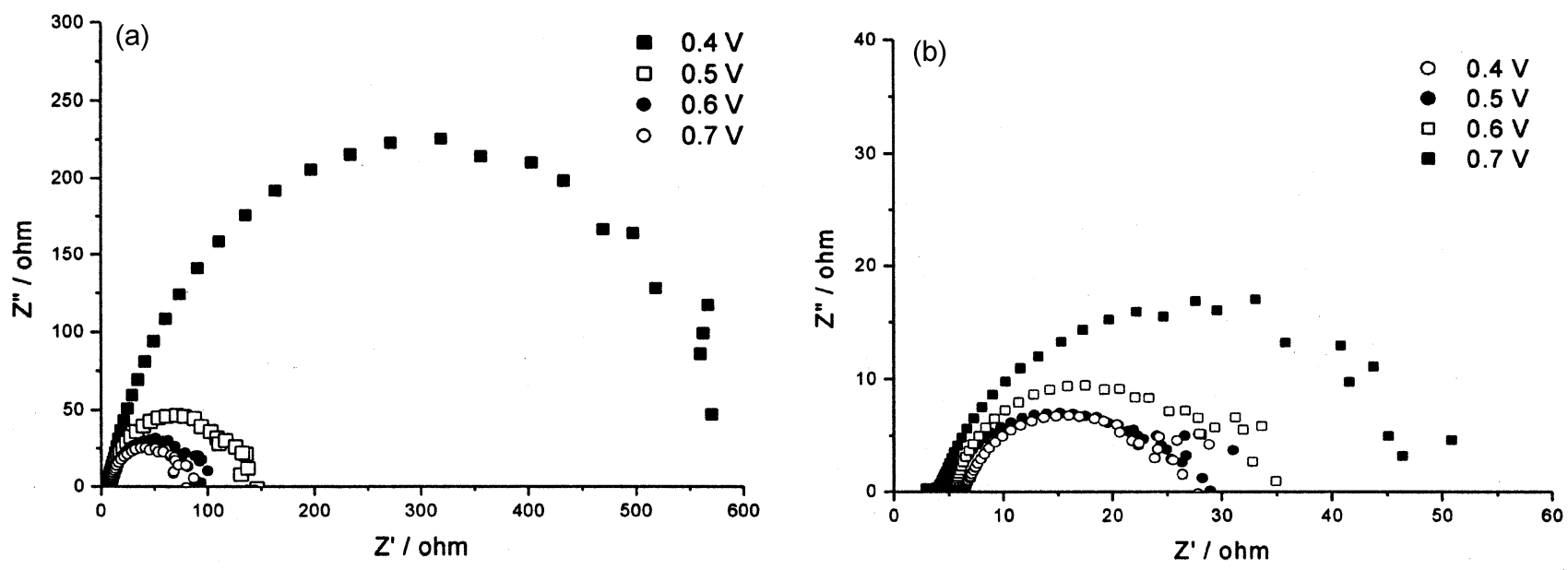

Figure 5. Impedance spectra at selected potentials of carbon supported platinum electrode in (a) $1.0 \mathrm{M}$ ethanol in $0 \cdot 5 \mathrm{M} \mathrm{H}_{2} \mathrm{SO}_{4}$, and (b) $1.0 \mathrm{M}$ 2-propanol in $0 \cdot 5 \mathrm{M} \mathrm{H}_{2} \mathrm{SO}_{4}$.

Table 3. Charge transfer resistances for the oxidation of $1.0 \mathrm{M}$ ethanol in $0 \cdot 5 \mathrm{M} \mathrm{H}_{2} \mathrm{SO}_{4}$ and on carbon-supported platinum electrode.

\begin{tabular}{lcc}
\hline & \multicolumn{2}{c}{ Charge transfer resistance, $R_{c t}(\mathrm{Ohm})$} \\
\cline { 2 - 3 } Electrode potential vs MSE $(\mathrm{mV})$ & Ethanol & 2-Propanol \\
\hline 400 & 609 & $23 \cdot 8$ \\
500 & 127 & $21 \cdot 0$ \\
600 & $81 \cdot 8$ & $28 \cdot 3$ \\
700 & $71 \cdot 8$ & $43 \cdot 7$ \\
\hline
\end{tabular}

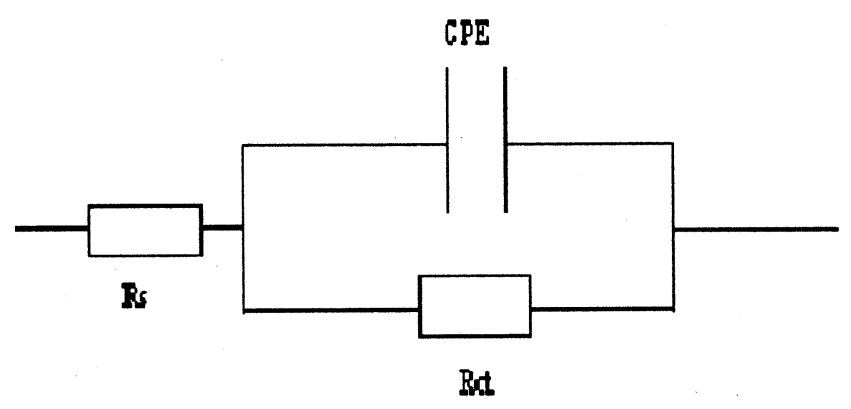

Figure 6. Equivalent circuit for the electrooxidation of ethanol and 2-propanol in $0.5 \mathrm{M} \mathrm{H}_{2} \mathrm{SO}_{4}$ at platinized carbon electrode.

Examination of figure 5 shows a significant decrease in the overall magnitude of $R_{c t}$ for 2-propanol oxidation in comparison with ethanol oxidation. This is justified by the initiation of 2-propanol oxidation at a lower overpotential than ethanol as has been observed in the cyclic voltammograms. The behaviour of Nyquist plots for the individual systems are likely to reflect the adsorption and desorption kinetics of the intermedi- ate species at selected potentials during the progress of the oxidation process. The highest charge transfer resistance observed at $0.4 \mathrm{~V}$ is indicative of the blockage of adsorption sites for ethanol and oxygen containing species. This blockage is due to the buildup of adsorbed intermediates. The rate of reaction begins to increase at $0.5 \mathrm{~V}$ indicating that the reaction is driven by a rapidly decreasing coverage of intermediate with increasing potential. Enhancement in the oxidative removal of the adsorbed intermediate caused by the formation of highly reactive chemisorbed hydroxy species results in the decreased surface coverage by reaction intermediates.

In contrast to the potential dependence of the Nyquist plots for ethanol oxidation, there is a continuous increase in $R_{c t}$ with increasing potential in the 0.4 $0.7 \mathrm{~V}$ range for 2-propanol oxidation. This increase in $R_{c t}$ with electrode potential is one account of the progressive blockage of active sites by reaction intermediates, though this effect is less pronounced in the case of 2-propanol. The blockage of the Pt surface at $0.7 \mathrm{~V}$ is also reflected in the CV of 2-propanol oxida- 
tion where the second oxidation peak current begins to decrease at this potential.

In view of the preceding results, the potentiality of 2-propanol as a liquid fuel for DAFCs can be ascribed to two factors. First, all possible intermediates and/or products formed during the oxidation of 2-propanol are predictably of a larger size than those for ethanol electro-oxidation (2-propanol is a secondary while ethanol is a primary alcohol) and consequently have a lower tendency to adhere to the Pt surface. Since 2-propanol oxidation currents are larger than those obtained for ethanol oxidation as measured during the polarisation studies, the electrode poisoning effect by reaction intermediates is arguably less for 2-propanol electro-oxidation. Second, the preference for 2-propanol is also due to the fact that its complete oxidation to $\mathrm{CO}_{2}$ generates 18 electrons as compared to 12 for ethanol oxidation.

\subsection{Variation of open-circuit potential with temperature}

Figure 7 shows the variation of open-circuit potential (OCP) with temperature for both ethanol and 2propanol fuel cells. OCP is found to increase with the rise in temperature. Notably, the OCP values measured for cells incorporating 2-propanol as the fuel are significantly higher than those with ethanol, especially for temperatures above $30^{\circ} \mathrm{C}$. Since $\left[\delta\left(\Delta E(/ \delta T]_{P}=S\right.\right.$, where the terms have their usual

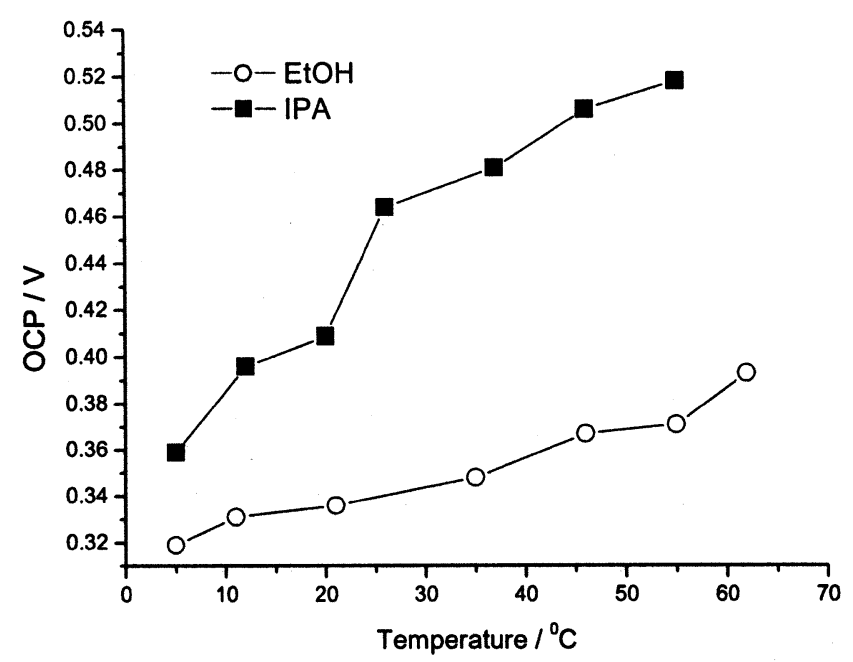

Figure 7. Variation of open-circuit potential of carbonsupported platinum electrode: (--O- $) 1.0 \mathrm{M}$ ethanol in $0.5 \mathrm{M} \mathrm{H}_{2} \mathrm{SO}_{4}$, and (-- - ) $1.0 \mathrm{M} \mathrm{2-propanol} \mathrm{in} 0.5 \mathrm{M}$ $\mathrm{H}_{2} \mathrm{SO}_{4}$. significance, the slope of the OCP vs temperature plot corresponds to the entropy of the system. Increase in entropy translates to a lesser degree of available thermodynamic work, which in turn curbs the electrical efficiency of a cell. Based on this, the thermodynamic significance of the results presented in figure 7 may be discussed.

It is observed that the OCP values for ethanol within the temperature range of $5-80^{\circ} \mathrm{C}$ corresponds to more or less a single slope. On the other hand, there is a steep rise in OCP values for 2-propanol up to a temperature of $\sim 30^{\circ} \mathrm{C}$ beyond which the slope of the OCP vs temperature plot diminishes. Higher slope translates to a significant increase in entropy of the system, which in turn curb the availability of thermodynamic work. In other words, elevating the operating temperature of the 2-propanol fuel cell in the temperature range of $5-30^{\circ} \mathrm{C}$ increases the OCP values, but at the expense of lowering the performance efficiency of the cell. It may be speculated that at temperatures below $30^{\circ} \mathrm{C}$ the electrooxidation of 2-propanol is much more sluggish compared to that at elevated temperatures. This is ascribed to various reasons like slow diffusion of large sized secondary alcohol molecules, steric hindrance during dissociative adsorption at the electrode surface and probable formation of pre-electrode layer effectively blocking the electrode/electrolyte interface. At elevated temperatures, however, the electrooxidation of 2-propanol becomes facile. Cao $e t a l^{37}$ found the performance of their cell operating on $2.0 \mathrm{M}$ 2-propanol to be substantially higher at $90^{\circ} \mathrm{C}$ than at $60^{\circ} \mathrm{C}$. Ethanol being a C-2 alcohol, the electrooxidation process is not as significantly affected by temperature variation as in the case for 2-propanol. Hence the OCP values for ethanol within the temperature range of $5-80^{\circ} \mathrm{C}$ corresponds to a single slope. However since 2-propanol shows a brighter regime of OCP values at temperatures above $30^{\circ} \mathrm{C}$, the potential use of 2-propanol at elevated temperatures may be preferred to that of ethanol.

\section{Conclusion}

In this work, a comparative study was carried out on the electro-oxidation of ethanol and 2-propanol on carbon-supported pt nanoparticles. On the basis of $\mathrm{CV}$, polarisation and EIS studies, it is concluded that the molecular structure of the alcohol undergoing oxidation has a considerable influence on its electroreactivity. Higher oxidation currents for 2-propanol have been obtained almost over the whole potential 
range as compared to ethanol oxidation, which is constrained by the need of higher overpotential than the former. This is interpreted in terms of 2-propanol not forming bound intermediates on the Pt surface thereby inhibiting poisoning of the electrode. A lower degree of blockage of the active sites is also reflected in the lower charge transfer resistance values for 2-propanol oxidation than are obtained in the case of ethanol. Further, since 2-propanol shows a brighter regime of OCP values at temperatures above $30^{\circ} \mathrm{C}$, the potential use of 2-propanol at elevated temperatures may be preferred to that of ethanol. Detailed studies will be performed in the future using spectrochemical techniques with the aim of identifying the adsorbed intermediates and elucidating the reaction mechanism.

\section{Acknowledgements}

We gratefully acknowledge the financial support by the Defence Research and Development Organization (DRDO), New Delhi.

\section{References}

1. Wasmus S and Kuver A 1999 J. Electroanal. Chem. 46114

2. Prabhuram J and Manoharan R 1998 J. Power Sources 7454

3. Gasteiger H A, Markovic N, Ross Jr P N and Cairns E J 1993 J. Phys. Chem. 9712020

4. Adzic R R, O'Grady W E and Srinivasan S $1981 \mathrm{~J}$. Electrochem. Soc. 1281913

5. Vassiliev Y B, Bagotzky V S, Osetrova N V and Mikhailova A A 1979 J. Electroanal. Chem. 97 63

6. Watanabe M and Motto S 1975 J. Electroanal. Chem. 60267

7. Takky D, Beden B, Leger J-M and Lamy C 1983 J. Electroanal. Chem. 145461

8. Rodrigues I A, De Souza J P I, Pastor E and Nart F C 1997 Langmuir 136829

9. Delime F, Leger J-M and Lamy C 1999 J. Appl. Electrochem. 291249

10. Iwasita T 2002 Third LAMNET Workshop Proceedings (Brazil) (Munich: WIP-Munich)

11. Iwasita T, Rasch B, Cattaneo E and Vielstich W 1989 Electrochim Acta 341073
12. Leung L-W H, Chang S-C and Weaver M J 1989 J. Electroanal. Chem. 266317

13. Tremiliosi-Filho G, Gonzalez E R, Motheo A J, Belgsir E M, Leger J-M and Lamy C 1998 J. Electroanal. Chem. 44431

14. Sun S-G and Lin Y 1996 Electrochim. Acta 41693

15. Sun S-G and Lin Y 1998 Electrochim. Acta 441153

16. Otomo J, Li X, Kobayashi T, Wen C-J, Nagamoto H and Takahashi H 2004 J. Electroanal. Chem. 57399

17. Beden B, Kadirgam F, Lamy C and Leger J-M 1981 J. Electroanal. Chem. 12775

18. Jansenn M M and Moolhuysen J 1976 Electrochim. Acta 21869

19. Hoster H, Iwasita T, Baumgartner H and Vielstich W 2001 Phys. Chem. Chem. Phys. 3337

20. Niu L, Li Q, Wei F, Chen F and Wang H 2003 J. Electroanal. Chem. 544121

21. Delime F, Leger J-M and Lamy C 1998 J. Appl. Electrochem. 2827

22. Shukla A A, Ravikumnar M K, Roy A, Barman S R, Sarma D D, Arico A S, Antonucci V, Pino L and Giordano N 1994 J. Electrochem. Soc. 141117

23. Khazova O A, Mikhailova A A, Skundin A M, Tuseeva E K, Havranek A and Wippermann K 2002 Fuel Cells 299

24. Frelink T, Visscher W and van Veen J A R 1995 Surf. Sci. 335353

25. Grgur B N, Markovic N M and Ross Jr P N $2003 \mathrm{~J}$. Serb. Chem. Soc. 68191

26. Lasch K, Jorissen L and Garche J 1999 J. Power Sources 84225

27. Sen Gupta S, Mahapatra S S and Datta J 2004 J. Power Sources 131169

28. Golabi S M and Nozad A 2002 J. Electronal. Chem. 521161

29. V A Application note no. V-67 (available at www. metrohm.com/infocenter)

30. Rodriguez J M D, Melian J A H and Pena J P $2000 \mathrm{~J}$. Chem. Educ. 91195

31. Bogotzky V S and Vassilyev Y B 1967 Electrochim. Acta 121323

32. Lamy C, Lima A, LeRhum V, Delime F, Coutanceau C and Leger J-M 2002 J. Power Sources 105283

33. Vielstich W 1965 Fuel cells: Modern processes for the electrochemical production of energy (New Delhi: Wiley-Interscience)

34. Xu Y, Amini A and Schell M 1994 J. Phys. Chem. 98 12759

35. Souza J P I, Rabelo F J B, Moraes I R and Nart I R 1997 J. Electroanal. Chem. 42017

36. Bard A J and Faulkner L R 1980 Electrochemical Methods (New York: J Wiley \& Sons)

37. Cao D and Bergens S H 2003 J. Power Sources 12412 